\title{
PECADO Y CONFESIÓN EN LA ESPAÑA MODERNA. LOS MANUALES DE CONFESORES.
}

\author{
ARTURO MORGADO GARCÍA \\ Universidad de Cádiz
}

In memoriam José Luis Millán Chivite

«Toma de la moral una tintura

y si tú quieres que te elija libro,

Lárraga el inmortal será el que leas,

que ha dado confesores infinitos» (1).

Arropada durante mucho tiempo por el velo del silencio, el secreto y el misterio que rodeaba al sacramento de la penitencia, la figura del confesor ha conocido en los últimos años una cierta popularidad desde el punto de vista historiográfico, especialmente en aquellos aspectos referidos a sus relaciones con el sexto mandamiento, hasta el punto que una nutrida fauna de confesores solicitantes, fornicarios y obsesos sexuales (2) puebla el cada vez más frondoso bosque de la historia religiosa de nuestro país. Pero es una visión parcial, tanto como lo era la imagen difuminada y etérea, casi mágica, de tiempos anteriores.

Es poco probable que cuando en el IV Concilio de Letrán (1215) la Iglesia Católica decretara la obligatoriedad de la confesión anual, se fuera plenamente consciente de la trascendencia que en el futuro tendría dicha medida (3). No sólo para unos fieles que a sus temores cotidianos, ya de por sí numerosos (4), añadirían la, en muchos casos traumática, experiencia de relatar sus vivencias, temores y frustraciones con cierta periodicidad; sino para unos clérigos que, en muchas ocasiones, no estarían a la altura de tan delicado ministerio, habida cuenta del fuerte grado de ignorancia que durante mucho tiempo caracterizó a buena parte del bajo clero. Porque erraríamos si pensamos que los confesores estaban hechos de una pasta especial: si bien para administrar dicho sacramento un sacerdote debía obtener licencia del obispo, que mandaba examinarle de moral por una persona de su confianza, en la mayor parte de los casos su concesión era un mero trámite (5). No es por ello de extrañar que las conferencias morales, uno de los principales arbitrios utilizados para «reciclar» periódicamente la : formación intelectual del bajo clero, insistieran con frecuencia en el principal auxilio que tendrán los confesores para desempeñar su misión: la Teología moral (6).

Si durante siglos ésta había estado estrechamente unida a la Teología dogmática, a partir del Concilio de Trento se independiza y comienza a enseñarse como disciplina autónoma, naciendo así los tratados de Teología moral como género independiente. Junto a las Instituciones, o explicaciones de 
la moral impartidas durante los cursos completos de la carrera eclesiástica, florecen a lo largo de los siglos XVI y XVII los manuales o sumas de casos, cuya razón de ser era la de prestar ayuda a los sacerdotes con cura de almas, poniendo en sus manos los conocimientos más imprescindibles para el conveniente desempeño de su ministerio, sumas que no contenían más que soluciones de casos concretos, sin abordar los problemas fundamentales de la moral. Si en un primer momento circularon todavía las clásicas sumas medievales, como el Confessionale de Antonino de Florencia (que en 1477 era impreso en Valencia por Alfonso Fernández de Córdoba) (7), poco a poco se imponen las escritas por los autores contemporáneos, como el Manual de confesores y penitentes (Lyón, 1575) de Martín de Azpilcueta, la Suma de casos de conciencia (Salamanca, 1594) de Manuel Rodríguez «Lusitano» y la Instrucción de sacerdotes (Lyón, 1599) de Francisco de Toledo. En todos estos autores, la solución de cada caso va acompañada de las respectivas pruebas teológicas. Pero con el tiempo, mientras aumentan los casos, disminuyen los argumentos teológicos, convirtiéndose así estas sumas en inmensos recetarios morales, y semejante tendencia a la casuística acabaría llevando al nacimiento del probabilismo (expuesto por primera vez por el dominico Bartolomé de Medina en 1577) y el laxismo, y con ello al descrédito de la Teología moral (8).

Pero dicho casuismo, a pesar de ser fuertemente criticado, vituperado y ridiculizado, era lo que se demandaba por los examinandos para obtener facultad y licencia para ejercer como confesores, por quienes seguían los cursos de moral y no tenían más remedio que hacer prácticas de la enseñanza teórica a base de infinidad de circunstancias que medían la cantidad y la calidad de los pecados, y por quienes asistían a las conferencias morales. Y las grandes estrellas, tales el Manual de confesores de Azpilcueta (9), la Práctica del confesionario de Jaime de Corella (21 ediciones entre 1686 y 1717) (10), o el celebérrimo Prontuario de la Teología moral de Francisco Lárraga (la primera edición es de 1706, y conoció más de setenta reediciones, la última ¡nada menos que en $\left.1950_{i}\right)$, servían a este propósito (11). Los grandes títulos, empero, no agotan el género ni mucho menos, y basta una mera consulta al repertorio bibliográfico de Palau (12) o a la obra de Nicolás Antonio (13) para comprobarlo: según Kamen, solamente entre 1500 y 1670 se editaron nada menos que 692 títulos de Teología Moral (14), de los cuales 403 lo fueron entre 1590 y 1649, la época dorada del probabilismo, siendo el objetivo final de toda esta literatura muy bien expresado por Fray Anselmo Gómez en 1668: «la experiencia que tenemos de los grandes yerros que suceden cada día entre los curas y confesores, a causa de ignorar muchas materias extravagantes que no andan en las sumas comunes...por cuyo idiotismo vemos venir algunos llamados y castigados por el Santo Tribunal de la Inquisición» (15). Sus autores, atendiendo a la información ofrecida por Nicolás Antonio, estarán vinculados preferentemente a las órdenes religiosas antes que al clero secular, con una fuerte proporción de jesuitas, dominicos y, en menor medida, franciscanos, entre sus filas.

La oferta, como vemos, era importante. ¿Cómo funcionó la demanda? Debió tener cierta incidencia, como se refleja del hecho de que el $3 \%$ de las obras 
presentes en la librería del impresor sevillano Lucas Martín de Hermosilla (1720) son incluidas bajo el epígrafe de «Moral» (16), y algunos exponentes del género aparecen bastante representados en los anaqueles de las estanterías del negocio de Jacobo Dnerbe (1751), tales el Fuero de la conciencia de Valentín de la Madre de Dios (la gran estrella, sin lugar a dudas, con 89 ejemplares, si bien esta cifra se aleja mucho de los más de 300 que alcanzan otras obras de literatura espiritual), De confesores de Azcalgorta, o la Práctica del confesionario de Jaime de Corella (17). A su vez, suponen el 2,5\% de los títulos presentes en las bibliotecas hispalenses de dicha centuria, si bien con una acentuada concentración de la demanda (dos tercios del total) en el estamento eclesiástico, lo que no es de extrañar dado el carácter abiertamente utilitario y profesional de este género (18).

En Salamanca los manuales de confesión aparecen incluso en algunas bibliotecas laicas, pudiendo destacar entre los más corrientes Enchiridion seu Manuale confessionariorum et poenitentium de Martín de Azpilcueta (1575), Medulla Theologiae moralis de Busembaum (1645), Suma de la Teología Moral de Jaime Corella (1693), Resolutionum moralium de Antonio Diana (1629), Theologiae moralis summa de Enrique Enríquez (1591-93), Suma en la cual se suma y cifra todo lo moral y casos de conciencia... de Pedro de Ledesma (1621), Suma eclesiástica o instrucción para los confesores y penitentes de Jerónimo Llamas (1605), Suma moral de Machado de Chaves (1661), Suma de casos morales de Bartolomé de Medina (1580), Singularia moralis Theologiae de Antonio de Quintanadueñas (1652), Suma de casos de conciencia de Manuel Rodríguez (1594), Catena eiusdem moralis de Pedro de Tapia (1651), Summa casuum conscientiae de Francisco Toledo (1601), Manual de confesores de Enrique de Villalobos (1625) (19)...

En Valencia, a su vez, el gran éxito editorial corresponde al Promptuario de Teología moral de Francisco Lárraga (1706), presente en algo más del 4\% de los inventarios de bibliotecas, seguido de lejos por las obras de Daniel Concina, el laxista Antonio Diana, y el Tribunal confesarium de Martín Wigand. La Teología moral de Busembaum, por su parte, era fácilmente asequible en los negocios libreros valencianos dieciochescos (20). Por lo que se refiere a los eclesiásticos gaditanos dieciochescos, la Práctica del confesionario y la Suma de la Teología moral, ambas de Jaime de Corella, estarán presentes en el 30\% de las bibliotecas clericales (21).

Desde el punto de vista formal, los Manuales de confesores (22) suelen estar organizados de forma expositiva hasta mediados del siglo XVII (una de las escasas excepciones anteriores la constituye la Suma de Fray Alonso Vega), aunque a partir de entonces es más habitual acudir al método de preguntas y respuestas, como sucede en las obras de Fray Anselmo Gómez, Noyden, Manero, Corella, Valentín de la Madre de Dios, Bernardo Pacheco o Vicente Ferrer (23). Su estructura, asimismo, variará con el tiempo en lo que se refiere al muestrario de los distintos pecados posibles. Si todavía en la obra de Azpilcueta se abordaban todas aquellas faltas cometidas contra los diez mandamientos del 
Decálogo, los cinco Mandamientos de la Iglesia, las obras de misericordia y los siete pecados capitales, este esquema se irá simplificando progresivamente, desapareciendo los pecados cometidos contra las obras de misericordia y los siete pecados capitales, e incluyéndose en muchas ocasiones los mandamientos de la Iglesia en el interrogatorio relativo al tercer mandamiento del Decálogo. Al mismo tiempo, los mandamientos $9^{\circ}$ y $10^{\circ}$ del Decálogo serán incluidos en el $6^{\circ}$ y $7^{\circ}$ respectivamente.

\begin{tabular}{|c|c|c|c|c|c|c|c|c|c|c|c|}
\hline Mandamientos & 1. & 2 & 3 & 4 & & 5. & 6. & 7. & 8. & 1 & $\operatorname{Ig} 1$. \\
\hline Azpilcueta (1557) & 32 & 28 & 10 & 19 & 11 & 24 & 124 & 38 & 7 & 2 & 32 pag. \\
\hline Pedraza (1567) & 26 & 10 & 15 & 10 & 12 & 21 & 39 & 13 & $6^{\circ}$ & 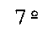 & - pre. \\
\hline Ortiz Lucio (1598) & 6 & 14 & 5 & 9 & 15 & 12 & 38 & 9 & 1 & 1 & - pag. \\
\hline Mártir Coma (1614) & 31 & 8 & 11 & 15 & 11 & 18 & 31 & 15 & - & - & - pre. \\
\hline Fdez. Córdoba (1622) & 31 & 19 & 26 & 54 & 40 & 34 & 33 & 23 & $6 \div$ & $7=$ & 35 pre. \\
\hline Fray Juan Enriquez (1634) & 14 & 18 & 3 & 5 & 9 & 1.1 & 27 & 12 & 1 & 1 & 11 pag. \\
\hline Busenbaum (1667) & 17 & 26 & 10 & 9 & 12 & 8 & 69 & 9 & 1 & 1 & 5 pag. \\
\hline Filguera (1667) & 18 & 4 & 3 & 8 & 5 & 7 & 5 & 5 & - & - & - pre. \\
\hline Noyden (1672) & 26 & 33 & 22 & 12 & 14 & 20 & 35 & 7 & 1 & 1 & - pag. \\
\hline Corella (1690) & 43 & 74 & 34 & 30 & 62 & 185 & 217 & 47 & $6 \%$ & 79 & $3 \cong$ pre. \\
\hline Madre de Dios (1704) & 5 & 14 & 20 & 8 & 11 & 40 & 56 & 19 & - & - & - pag. \\
\hline Lárraga (1709) & 47 & 40 & 27 & 5 & 13 & 14 & 74 & 17 & 1 & 1. & $3^{2} \mathrm{pag}$ \\
\hline García (1726) & 12 & 24 & 6 & 6 & 7 & 4 & 42 & 3 & $6 \circ$ & - & 17 pag. \\
\hline Echarri (1749) & 34 & 29 & 3 & 8 & 16 & 20 & 22 & 11 & 1 & $I$ & - pag. \\
\hline Cliquet (1759) & 62 & 35 & 19 & 4 & 7 & 13 & 46 & 13 & - & - & - pag. \\
\hline Ascargorta (1762) & 46 & 9 & 12 & 8 & 13 & 4 & 22 & 2 & 1 & 1 & 7 pag. \\
\hline Ferrer (1771) & 81 & 33 & 41 & 9 & 13 & 7 & 36 & 3 & 1 & 1 & $17 \mathrm{pag}$. \\
\hline Arceniega (1783) & 13 & 10 & 3 & 3 & 15 & 41 & 17 & 3 & - & - & - pag. \\
\hline
\end{tabular}

Evidentemente, también es distinta la importancia concedida a cada uno de los pecados. Contra lo que pudiera parecer, no es el sexto mandamiento el que polariza la atención (el cual, como es bien sabido, aborda la lujuria en todas sus formas) (24), y solamente en la obra de Arceniega recibe el tratamiento más extenso, siendo de destacar el interés suscitado por el séptimo (en 11 de 18 manuales es el más tratado, y en uno más empata con el primero), en el cual se tratan la variadísima gama de usuras, préstamos a interés, contratos, censos...aunque en los manuales del siglo XVIII han experimentado un gran avance las exposiciones relativas al primer mandamiento (en 5 manuales es el predominante, $y$ todos menos uno datan de dicha centuria), lo que puede mostrar una creciente preocupación por los aspectos meramente doctrinales.

Pero los Manuales de confesores ofrecen mucho más que un repertorio de todos los pecados posibles prolijamente clasificados, analizados y desarrollados (profusión, por otro lado, que hay que poner en conexión con el desarrollo de la casuística promovido por el impacto de las ideas probabilistas). El clásico «Lárraga» nos aportará además bastantes páginas dedicadas a los sacramentos, las distintas censuras practicadas por la Iglesia (excomunión, suspensión, entredicho), una serie de meditaciones sobre el carácter de las acciones humanas (donde entraría el tratamiento de la conciencia segura, dudosa y probable), la bula de la Cruzada...pero, ¿cuáles son los grandes temas tratados por toda esta 
literatura?, una literatura, por otro lado, que, a tenor de sus títulos, se pretende ante todo «breve» $\mathrm{y}$ «útil»...lo que vale tanto para ministros ignorantes como apresurados.

\section{UN COMPENDIO ELEMENTAL DE TEOLOGÍA.}

Los Manuales de confesores constituyen, ante todo, un compendio elemental de teología en el que se abordan todas las cuestiones relativas al sacramento de la confesión, tomando una postura muy flexible (aunque en el siglo XVIII esta flexibilidad ya no sea tan universal como en tiempos anteriores) ante las principales controversias teológicas de la época.

Así, por lo que se refiere a la polémica entre dolor de atrición y de contrición, que tanta literatura generara (25), los manuales españoles en muchos casos admiten aquélla como suficiente para el perdón de los pecados (26). Bartolomé de Medina, por ejemplo, acepta las dos situaciones (27). Francisco de Toledo distingue entre los pecados mortales, para los cuales la atrición no es suficiente, de los veniales, para los que basta. No obstante, matiza un poco sus opiniones, señalando que «no es necesario que se tenga de todos los pecados mortales cometidos 'sino sólo de aquéllos que por semejante acto de contrición no se han perdonado porque para perdonar los pecados mortales de que uno piensa ha tenido contrición o que se ha confesado no es necesaria nueva contrición» (28). Villalobos sostiene que «la atrición es bastante disposición para recibir el sacramento de la penitencia aunque el penitente eche de ver sólo lleva atrición. Y por el sacramento de la penitencia se hace el que le recibe de atrito contrito porque le da gracia y caridad y con ella se infunden las virtudes morales, $y$ así se infunde el hábito de la penitencia cuyo acto es la contrición. $Y$ así queda contrito habitualmente el que llegó con acto de atrición aunque este acto no se muda en acto de contrición» (29). Corella, por su parte, piensa que el dolor de atrición es bastante para el perdón de los pecados (30).

Como no podía ser menos, el auge que adquiere el probabilismo durante esta época también se refleja en los Manuales de confesores. Su edad de oro se prolongará, precisamente, entre 1577 y 1655 , aunque a partir de este momento los ataques jansenistas (destaquemos las obras de Pascal) y las condenas pontificias contra aquellas proposiciones probabilistas más extremas contribuirán a su decadencia (31). Sea como fuere, los Manuales de confesores contemplan en más de una ocasión la posibilidad de que en algunas situaciones específicas exista el riesgo de duda acerca de la licitud de ciertas cuestiones. Rodríguez Lusitano señala al respecto:

«Guárdese el confesor de condenar por pecado mortal lo que no sabe cierto si lo es antes en las cosas dudosas lléguese a la parte más segura y en las dificultosas sepa dudar...Que atravesándose en la confesión algún caso en cuya determinación hay pareceres contrarios de doctores graves de los cuales unos sigue el confesor y otros el penitente y el confesor cree su opinión ser evidente y la del penitente fundarse en una razón frívola y dudosa no le debe en este caso 
absolver empero si las razones de entrambas las opiniones corren a parejas o a lo menos la del penitente tiene probabilidad por lo cual es seguida de un doctor grave puede el confesor conformarse con la opinión del penitente aunque no sea su párroco y confesarle y absolverle» (32).

Con el tiempo, las «opiniones probables» estarán presentes en muchos manuales. Villalobos cree que «es lícito seguir opinión probable aunque haya otra más probable y algunos tienen lo contrario de esto y aunque yo tenga mi opinión por más probable y sea más segura siendo la contraria probable la puedo seguir en práctica...cuando el confesor confiesa a otro más docto que él o persona que sigue opinión probable tiene obligación a seguir la opinión del penitente» (33). Según Filguera, «como nadie está obligado a hacer lo que es mejor sino que basta que haga lo que es bueno y honesto de la misma manera ninguno está obligado a hacer lo que es más probable sino que es suficiente que haga lo que es probable» (34). Fray Juan Enríquez lo expresará muy claramente en 1646:

«Es necesario advertir que el conocimiento cierto de las cosas es tan dificultoso en unas y tan imposible en otras que si hubiese obligación de saber con certidumbre lo que es lícito obrar apenas se podría obrar alguna cosa. Y así por ser este conocimiento tan dificultoso o imposible convienen los doctores en afirmar que ni Dios obliga a este conocimiento ni es necesario para obrar con seguridad de conciencia sino que basta un conocimiento probable práctico que afirme con probabilidad que tal cosa es lícita o no es lícita y que éste basta para obrar con seguridad de conciencia...No hay obligación en conciencia a seguir la opinión más segura ni de la parte más segura sino que lícitamente y con segura conciencia se puede dejar la opinión más segura y seguir la opinión de la parte menos segura siendo probable prácticamente...no aciertan algunos hombres doctos cuando refiriendo opiniones contrarias de otros escogiendo ellos la opinión de la parte más segura dicen que se siga aquélla porque es más segura sabiendo que aunque sea más segura ni hay obligación de seguirla no habiendo peligro alguno como hemos dicho en seguir la opinión de la parte menos segura...no hay obligación en conciencia de seguir la opinión más probable en los casos de teología moral sino que basta seguir la probable» (35).

Un tercer aspecto en el cual se manifiesta esta flexibilidad doctrinal es en la forma de cumplimentar la penitencia (que casi nunca se tarifa en relación al pecado cometido) (36), siendo muy diversos los arbitrios posibles: según Azpilcueta se reducen al ayuno, oraciones y limosnas, resumiéndose las vigilias, peregrinaciones y obras que afligen a la carne al ayuno, las obras de misericordia corporales a la limosna y las espirituales a la oración, siguiendo al franciscano Scoto Erígena (37). Para Corella, las obras más meritorias son la limosna «que comúnmente se ha de imponer a cada uno según su posibilidad», oír misa, visitar el vía crucis y el ayuno, siempre que se trate de «personas robustas y desocupadas» (38). Enríquez opina que siempre que el confesor pudiera imponga como penitencia oir misa en día no festivo, ya que «no hay penitencia 
que más fácilmente șe cumpla ni que para las almas sea más fructuosa ni más acomodada para todos ni más conveniente para la honra de Dios» (39).

El confesor debe ser muy cuidadoso en elegir la penitencia más conveniente, que ha de ser siempre justa (de hecho, «aunque yerra el confesor cuando impone en la confesión menos penitencia que merecen las culpas...más yerra cuando las impone mayor que el penitente merece») (40), adaptándose a la gravedad del pecado, al arrepentimiento demostrado por el penitente (la penitencia podrá aminorarse, en opinión de Valentín de la Madre de Dios, si se muestran grandes señales de contrición) (41), y a su condición concreta. De este modo, y siguiendo a Azpilcueta, «debe considerar...si es rico o pobre que ha de trabajar para que no imponga penitencia desconveniente cual sería la de dar limosna al pobre el ayuno al continuo trabajador austeridades grandes de persona al rico y de alto estado cual la que se da a la mujer hijo esclavo o criado tal que no la puede cumplir sin faltar notablemente al servicio del marido padre señor o amo o sin peligro de caída espiritual o de descubrir el pecado oculto...cual la de romerías y peregrinaciones para las mujeres a quien no conviene ir allá...mayormente sin sus maridos ni aun mucho con ellos pues pueden visitar espiritualmente los santos estando en sus casas. Cual la de pan y agua y soledad al melancólico escrupuloso. Y la de rezar mucho al que tiene grandes horas y lecciones» (42). Esta adaptación a las circunstancias particulares de cada penitente también la encontramos en Francisco de Toledo, que señala cómo «debe atender la calidad de la persona mirando donde sus fuerzas llegan. Puede el confesor disminuir en parte la penitencia...cuando el penitente es tan imperfecto que se teme de él o no aceptará la penitencia o si la acepta que no la cumplirá...cuando el penitente tiene algún impedimento o porque es ciego o tiene poca salud o por otras causas...cuando por otra vía se aumenta la penitencia y satisfacción» (43).

Pero, ¿cuánta penitencia? Arceniega nos contesta a esta pregunta, mostrando una serie de cánones extraídos de las instrucciones de Carlos Borromeo para la administración del sacramento de la penitencia (44) que nos revelan cómo las penas son bastante duras, aunque responden a una normativa bastante antigua. $\mathrm{Y}$ los mayores castigos no se relacionan forzosamente con pecados cometidos contra el sexto mandamiento: ciertamente, el adulterio es condenado con siete años de penitencia para el varón y cinco para la mujer, el incesto con doce años, y la bestialidad con diez; pero no lo es menos que el apóstata hará diez años de penitencia, el que hiciere encantos diabólicos siete, el que consultare a los magos cinco, el que hiriera a sus padres siete, el infanticidio es castigado con doce años, el aborto con tres, el homicidio con siete, el robo sacrílego con otros tantos...si bien los Manuales consultados normalmente omiten la inclusión de las tarifas penitenciales, Vicente Ferrer advierte que «aunque las satisfacciones que prescriben se hayan moderado y sólo fueran para penitencia pública y solemne, sin embargo no puede presumirse que no fuesen justas y proporcionadas al reato de la pena temporal correspondiente a las culpas...por lo cual debe el confesor advertir a los penitentes para que entiendan cuán moderadas son las penitencias que suelen imponerse que aun tal vez 
rehusan admitir y que no son bastantes para extinguir todo el reato de la pena temporal» (45).

La flexibilidad doctrinal de los manuales españoles se manifiesta también en la actitud adoptada, cada vez más abierta, ante la recepción frecuente de la Eucaristía por parte de los fieles en algunas circunstancias específicas (46), aunque casi nunca se llega a defender la comunión diaria (la única excepción la constituye Filguera, para el cual es «más conveniente y mejor consejo comulgar todos los días no habiendo conciencia de pecado mortal que dejar de comulgar aunque se deje la comunión por reverencia») (47). Para Medina, «hacer regla ordinaria que todos comulguen de ocho a ocho días es mala doctrina porque no todas las personas tienen igual devoción y aparejo...lo segundo que por más santo que sea un seglar no se ha de dar licencia que comulgue cada día sino a lo sumo cada semana» (48). Francisco de Toledo señala que «no se les ha de aconsejar a todos la misma frecuencia especialmente a los legos porque hay muchos que no tienen el conocimiento y discreción bastante para penetrar la dignidad de este sacramento como los rústicos y esclavos... y a los tales les basta el comulgar cada mes...otros penetran más pero ocupados con el cuidado de casa y familia y negocios seglares no pueden tener el alma apartada del todo de pensamientos terrenos y a estos les basta comulgar cada quince días. Otros aunque ocupados con negocios no se distraen tanto como los estudiantes y otros aun de los casados y a estos sería conveniente comulgar los domingos. No se ha de aconsejar el comulgar más a menudo universalmente sino remitir esto al juicio de los confesores» (49). Enrique de Villalobos opina que «los seglares...basta que comulguen de ocho a ocho días y si hubiere alguna fiesta en la semana con consejo del confesor. Y tanta podría ser la santidad del seglar que se le pudiese conceder cada día mas esto no ha de ser a cada paso mayormente a mujeres que son fáciles de engañary algunos prelados con razón han prohibido que nadie comulge cada día sin su licencia. Mas no es lícito comulgar dos veces en un día» (50).

Con el tiempo, empero, este talante tan comprensivo se va difuminando, no debiendo ser ajeno a este hecho las sucesivas condenas papales formuladas a lo largo de la segunda mitad del siglo XVII contra determinadas proposiciones probabilistas, así como, ya en el siglo XVIII, la progresiva difusión de las ideas jansenistas (51). De este modo, la concesión de la absolución ya no será tan fácil como antaño: aunque Valentín de la Madre de Dios piense que la dilación de ésta «rara vez y con gran discreción se ha de hacer» (52), Arceniega señala que «conviene que los fieles sepan a quien se debe negar o dilatar la absolución para que entiendan qué confesores deben elegir y de quienes debe huir porque hay muchos directores ciegos y homicidas de las almas que son nimiamente fáciles en dar la absolución a quien no se debe con lo cual son causa de que los penitentes falsamente confiados en que están absueltos nunca se apartan de sus pecados y nunca dejen sus malas costumbres y así como nunca son reprobados nunca reprendidos nunca enseñados en el camino de la justicia, perecen miserablemente y se condena» (53). 
Las opiniones probables se verán cada vez más restringidas: primero, limitando el contenido de las mismas, tal como hace Lumbier, para el cual no se puede tomar como opinión probable la mencionada por un sólo autor moderno, advirtiendo que «atiendan mucho a esto algunos que parece que estudian en buscar ensanches para las conciencias en especial para las monjas que les suelen enseñar sus devotos...ni se excusen con que lo hallaron en algún libro. Lo primero porque no debieran dar crédito a tal libro a vista de tantos que decían que era improbable.'Lo segundo porque no todos pueden fiarse de uno ni dos libros cuando las doctrinas traen consigo disonancia porque no todos pueden entender ni hacer juicio de los tales libros» (54). Manero precisará todavía más cuales son estas opiniones probables: «aquellas razones firmes y verdaderas y que están aprobadas con autoridad de muchos autores...que no tenga error alguno...que no esté prohibida por alguna ley o precepto, pero no se requiere muchedumbre de autores para que sea opinión probable sino que basta un autor que sea docto y de buena conciencia» (y no cualquier autor) (55).

Y, finalmente, la restricción llegará por imponer al penitente la obligación de elegir en todo caso la opinión más segura. Para Echarri, «si necesariamente has de hacer una de dos cosas y dudas a cual de ellas te has de inclinar no hallando a quien consultar deberás elegir lo más seguro o aquello en que no hay peligro de errar...no es lícito obrar con opinión de tenue probabilidad o con opinión dudosamente probable» (56). Cliquet, arrepintiéndose de sus anteriores opiniones laxistas (no olvidemos su condición de agustino, y es bien sabido que las posturas jansenizantes alcanzaron una gran influencia en dicha orden religiosa), señalará cómo «me acuerdo que antiguamente dije que se podía seguir la opinión menos probable y menos segura pero habiéndolo mirado mejor y conociendo por mí mismo que nuestras conciencias como de gente miserable más necesitan de freno que la sujeten que de doctrinas probables que las ensanchen...para caminar con menos riesgo al cielo debemos seguir la opinión más segura y más probable» (57). El rigorista Vicente Ferrer, aludiendo al abandono de Cliquet del bando probabilista, mostrará cómo «esto es realmente una gran prueba de la verdad de nuestra sentencia, que nadie la abandonó después de haberla abrazado, cuando se experimenta una continua deserción del probabilismo» (58).

\section{AVISOS AL CONFESOR.}

En segundo término, los Manuales de confesores ofrecen una serie de recomendaciones prácticas al confesor para que éste las tenga en cuenta a la hora de desarrollar su ministerio, haciendo fundamentalmente hincapié en la necesidad de ganarse la confianza del penitente.

Resulta evidente, en primer término, que no todo sacerdote está preparado para impartir un sacramento tan delicado: el confesor, según explica Corella, es a la vez jueż, maestro y médico. Como juez lo que primero debe hacer es dilucidar si el pecado cometido es mortal o venial. Como maestro, intentar erradicar la ignorancia del penitente enseñándole a distinguir entre el pecado 
mortal y el venial, cómo hacer examen de conciencia y conocer todo lo necesario para una buena confesión. Como médico, finalmente, debe dar «saludables medicinas al penitente según lo pidieron los achaques de sus pecados...y también con suaves amonestaciones pintarle la fealdad de sus culpas motivándole al aborrecimiento de ellas» (59).

Según Azpilcueta, el confesor, para bien ejercer su ministerio, ha de tener poder, saber y bondad. El poder consiste en que sea presbítero y tenga jurisdicción del ordinario para ello, si bien in articulo mortis cualquier sacerdote, aún sin licencia, puede oír la confesión del moribundo y absolverle de cualquier excomunión. La segunda condición es saber, que ha de incluir conocimientos de Teología, Cánones, Leyes y las constituciones sinodales del obispado donde esté destinado. No obstante, en la práctica es suficiente con conocer los pecados que comúnmente se cometen, cuáles son mortales y veniales, las circunstancias que se han de confesar, los pecados que llevan aneja la excomunión, y los casos en que se incurre en irregularidad en el caso de que confiese a clérigos. Navarro muestra una clara adaptación a las circunstancias, señalando que «cualquier que es idóneo para confesar a un hombre o en lugar no será idóneo para confesar a otro ni en cualquier lugar, que es un gran desengaño para muchos. Quien se pone a confesar en una aldea de simples labradores no ha menester saber tanto cuanto quien en una ciudad ni quien se pone en una ciudad mediterranea tanto como quien en una marítima ni quien en ésta tanto cuanto quien en todo un reino o una India ni tanto quien confiesa do hay muchos letrados con quien a confesarse do no hay ninguno...cuando las personas que se confiesan viven espiritualmente y se confiesen muchas veces y así no tienen comúnmente sino pecados veniales...cuando el penitente está en el artículo de la muerte y no hay quien lo confiese sino él. Y por la misma razón decimos lo mismo de los que están entre moros y gentiles, presos o sueltos, cautivos o libres, y no tienen quien los confiese sino algún tal ignorante» (60). Idéntica adaptación a las circunstancias mostrará Quintanadueñas, que opina que el confesor debe conocer «si confiesa a mercaderes o veinticuatros o otras personas particulares de las repúblicas sus obligaciones graves tratos y contratos y casos difíciles» (61).

La bondad es la tercera cualidad que ha de caracterizar al confesor, entendiendo ésta al menos como la ausencia de pecado mortal, ya que si en estas circunstancias confesara o absolviera pecaría gravemente, si bien dicha absolución sigue siendo válida (62). Para Jaime de Corella, el confesor debe llevar una «vida ajustada sus costumbres santas y su conversación edificativa», no tener familiaridad con sus penitentes ni aceptar dádivas de ellos, y estudiar todo lo relativo a las materias morales y casos de conciencia (63). Pero la realidad no siempre es tan halagueña y no siempre responde al modelo ideal, destacando Corella las lacras presentes en algunos confesores:

«No quieren curar las almas enfermas los que pudiendo aplicarse a su remedio por su conveniencia omisión ociosidad o pusilanimidad no se dedican al fructuoso empleo del confesionario.. No quieren otros dar salud a las enfermas 
conciencias aunque sepan el modo de curarlas...porque no se sientan en la silla del confesionario con deseo eficaz de sanarlas sino sólo con fin de confesarlas o despachar con ellas brevemente: espacio considerado y tiempo reposado es necesario para examinar al penitente...No niego que alguna vez se puede abreviar la confesión cuando el alma viene bien dispuesta, es persona capaz y trae la conciencia llana...denme que todos sean tan buenos penitentes como San Pedro que no tengan más enredadas las conciencias que los despachen brevemente, mas siendo las conciencias de otra calidad y las disposiciones de otro género, las culpas más repetidas y envejecidas, ¿cómo se ha de ajustar el remedio de estas almas en un corto tiempo? (64)...»

Ni que decir tiene que el summum del antimodelo vendrá dado por los confesores solicitantes, de ahí que Ortiz Lucio, para evitar este problema, recomiende confesar mujeres «en lugares patentes y no las mire al rostro ni se detenga en pláticas "con ellas antes ni después», abogando porque sean denunciados ante el tribunal de la Inquisición (65), opinión que también aparece reflejada en la obra de Fray Anselmo Gómez (66). Lárraga mostrará cómo la solicitada que no denuncie al confesor al tribunal de la Inquisición cae en la pena de excomunión mayor (67), llegándose a negar la absolución al penitente que no formule dicha denuncia (68).

El confesor debe hacer todo cuanto esté en sus manos por ganarse la confianza del penitente y no espantarle, a fin de que éste confiese todos sus pecados, benevolencia que, por otro lado, es un lugar común, encontrándose desde Santo Tomás de Aquino hasta San Alfonso de Ligorio (69): tal como bien expresa Lárraga, «el confesor sea suave en oir y eficaz en exhortar y que pregunte lo común y regular al estado ayudando al penitente con sus preguntas y procurando no enseñar nuevos modos de pecar con preguntas extraordinarias» (70). Echarri insistá en que el interrogatorio al penitente se realice «con suave y humano modo atendiendo siempre a la condición humana para que este sacramento no se haga gravoso» (71). Jaime de Corella llegará a exhortar a los confesores a que «sean afables con los pobres penitentes no les reprendan con asperea no los reciban con desazón no se espanten de sus culpas sino atiendan a la suma fragilidad de la mísera naturaleza humana y que si Dios a todos no nos tuviera de su mano seríamos peores que los demonios... advierta el confesor que en aquel tribunal sagrado de la confesión representa la persona de Dios y si la bondad divina en su tribunal se inclina más a la piedad que al rigor debe el confesor hacer lo mismo» (72). El mismo Corella da numerosas recomendaciones prácticas para ganar esta confianza:

«El modo con que el confesor se ha de portar...procurar huir los rincones sospechosos y ponerse a confesar en parte decente y pública nunca confesar en aposentos o casas particulares sin urgente necesidad, tener los ojos fijos en tierra, no mirar al rostro al penitente ni preguntarle jamás quien es ni de donde ni cómo se llama y aunque le conozca hacerse el desentendido y no mostrar que le conoce...procurar que la gente no se acerque demasiado por el riesgo de que pueden oir algo de la confesión...no dejarse llevar de la pasión de confesar a las 
personas ricas y nobles dejando a las pobrecitas ni de confesar a las mujeres dejando a los hombres ni muestre el estar deprisa ni quiera llevar atropellada la confesión...sea cuidadoso en preguntar todas las circunstancias que importan para hacer juicio del número y especies de las culpas y no sea demasiado nimio en introducir preguntas curiosas e impertinentes singularmente en cosas obscenas. Nunca muestre mal modo al penitente ni le trate con aspereza ni con palabras desabridas ni enfado ni le reprenda hasta acabar de decir todas las culpas...debe tratar con suavidad y afabilidad a los pobres penitentes pero no con sobrado cariño a las mujeres ni con palabras halagueñas...ha de portarse con mujeres con una entereza suave y una suavidad modesta, una compostura agradable y un agrado cauteloso. En dar las penitencias no sea aceptador de personas sea recto juez que atienda al proceso de las culpas y no a la calidad de ser la persona rica o pobre noble o plebeya...importa mucho que los confesores, con sagacidad y maña, amor y blandura, pregunten siempre a los penitentes al principio de la confesión si han callado algun pecado por verguenza y si la persona es tal que se puede sospechar esté enredada con este lazo del demonio" (73).

Aunque Rodríguez Lusitano indica que los confesores no absuelvan a todos aquellos penitentes que desconozcan la doctrina cristiana (74), otros autores manifiestan una actitud algo más flexible, quizás porque se ha tomado conciencia de las limitaciones con las que se ha topado la ofensiva doctrinal de la Reforma Católica (75). Ortiz Lucio, por ejemplo, piensa que si el penitente «tiene ignorancia invencible que ni puede ni debe vencer como es que la mujer que tiene cree que es suya y aunque vea el confesor que no es verdadero matrimonio puede callar aquel impedimento que él sabe que hay y no lo declare si sabe que con buena fe están casados y no se pueden bien remediar. Y dije con ignorancia invencible que puede haber en hombres rústicos del derecho oscuro como es si herir al clérigo es excomunión y así si no sabía la prohibición de los deudos y ignoraba el hecho» (76). Enríquez, por su parte, sostiene que «algunos hombres rústicos de muy bronco entendimiento que tienen natural impotencia de poder saber todos estos misterios que son necesarios les excusa de culpa su impotencia y así los confesores no los han de obligar a que los sepan todos porque hay algunos hombres de éstos tan incapaces que aunque se los enseñen y se los digan los oyen a manera de brutos» (77). El confesor, empero, no debe resignarse a esta situación, $\mathrm{y}$ ha de enseñar la doctrina cristiana en todos estos casos, sobre todo los diez mandamientos de Dios y de la Iglesia, los artículos del Credo, y los misterios de la Trinidad y la Encarnación (78), añadiendo así a sus numerosas funciones la de maestro: no se trata sólo de perdonar y consolar, sino también la de instruir. Pero estas recomendaciones nos muestran la resignación de la jerarquía eclesiástica ante la evidencia de que nunca dejaron de existir «Indias» en España (79).

Pero, ¿qué ha de preguntar el confesor al penitente? Azpilcueta se limita a señalar que ha de tener sumo cuidado con interrogarle tan sólo acerca de los pecados más comunes, sin detenerse en «los pecados ocultos que los muy maliciosos han inventado» ni en descender a particulares en los asuntos de la 
carne (80). Medina es más explicito, e incluye un interrogatorio previo a la confesión de los distintos pecados que, con leves variaciones, encontraremos en casi todos los manuales: el estado del penitente, si es casado o no, si tiene hijos o no, su oficio, qué tiempo ha que se confesó, si ocultó en aquella ocasión algún pecado concreto, si cumplió con la penitencia impuesta y si ha restituido en caso que el confesor así se lo hubiera ordenado (81)...todo ello destinado al conocimiento por parte del confesor de las circunstancias concretas del penitente (en clara conexión con la idea de la existencia de pecados específicos de cada estado), así como el grado de cumplimiento en ocasiones anteriores de este sacramento.

\section{UNA VISION ORGANICISTA DE LA SOCIEDAD.}

Médico de almas, el confesor ha de prestar especial atención a las enfermedades características de las distintas profesiones (82), por lo que no es de extrañar que los Manuales de confesores funcionen como un libro de estados en el que aparecen claramente explicitados los distintos deberes de todos los grupos sociales (83), señalando cómo en cada uno de ellos se puede encontrar la salvación, si bien en los Manuales del siglo XVIII ya no se encuentran referencias a estos pecados específicos: el último testimonio encontrado es el de la obra de Miguel García, que se limita a abordar los estados eclesiástico, religioso y monjil (84). Pero, hasta entonces, la descripción de los distintos estados es un lugar común. Alcocer, por ejemplo, manteniendo una visión claramente organicista de la sociedad, indica al respecto:

«Es la república como un cuerpo, en el cual hay diversos miembros que tienen distintos oficios necesarios todos para ser perfecto el cuerpo. Así en la república hay diversos estados, caballeros, ciudadanos y plebeyos y diversos oficios y artes $\sin$ las cuales no podría pasar la república ni ser perfecta, y todas ellas, usándose para servir a Dios y a la república y sustentar su persona y casa, guardada la ley natural divina y humana las acepta Dios y se merece en ellas estando en gracia...si cada uno en su oficio guardara la ley natural, divina y humana usará de él lícita y santamente...de esta doctrina del Espíritu Santo se aprovechen los tratantes y todos los que tienen alguna grangería, o otra manera de vivir: conviene a saber, que consulten con hombres doctos y temerosos de Dios, cómo usarán de sus tratos, oficios y grangerías lícitamente y sin ofender a Dios...los oficios de los jueces, abogados, escribanos y procuradores, y los tratos de los mercaderes y cambiadores, y algunos otros suenan mal entre la gente, poorque creen que no usan de ellos cono deben, pero muchos usan de ellos bien y sirviendo a Dios y a su república, y guardan lo que la ley le manda...Hay también algunos estados muy aparejados para servir a Dios y los que escoge Dios para ellos, dichosos se pueden llamar. Entre los señalados beneficios que Dios hace a los cristianos, uno de los más aventajados es escogerle para se servir de él en alguna religión (85). Porque todas las religiones son escuelas de virtud y de servir a Dios, y los ejercicios que se usan en ellas de día y de noche y de toda la vida son servir a Dios en todo cuanto hacen...Colígese de todo lo dicho que cada uno en su estado y oficio puede merecer gracia y gloria, usándole según la 
ley natural divina y humana para servir a Dios y a su república, y sustentar su persona, familia y casa, aunque algunos oficios y estados son más acertados a Dios de suyo y en que hay mucho mayor aparejo de servirle. A los que Dios escogiere para los tales estados y oficios denle muchas gracias y conozcan la merced que les hace en escogerlos para servirse de ellos y ocupen el tiempo en obras y ejercicios muy virtuosos» (86).

Es necesario que el confesor conozca la realidad de la complejidad social, «para que sepa examinar a cada uno de cualquier estado y condición que sea y remediarle conforme a su necesidad» (87). La conciencia de esta diversidad es tal que Machado señala cómo

«Los prelados y examinadores pregunten a los que...desean ser confesores la noticia general que deben tener de las obligaciones especiales de cada uno de los tres estados de la república cristiana que son eclesiástico religioso y secular y por lo menos la de aquellas personas para quienes pide la aprobación el confesor...de manera que el que pide aprobación para ser conesor de las personas eclesiásticas sepa de las obligaciones especiales de cada una de ellas conviene a saber qué pecados puede cometer por razón de su oficio un clérigo de menores órdenes qué el subdiácono diácono sacerdote cura prebendado etc. Y si pide aprobación para confesar seglares sepa también las obligaciones generales y los pecados propios de cada uno de los de ese estado, esto es, qué pecados pueden cometer por razón de su oficio los señores supremos, los jueces superiores e inferiores, los ministros y demás personas que intervienen en el despacho de los pleitos, las obligaciones de los mercaderes y de todos los demás que en la república tienen tratos y granjerías o por razón de sus oficios y estados pueden cometer especiales pecados como son los casados los padres hijos tutores pupilos esclavos criados etc» (88).

Dichos estados varían según los distintos manuales de confesores, así como la importancia de cada uno de ellos, aunque siempre se presta una mayor atención a los estratos superiores de la sociedad, al clero y al mundo de la judicatura (89): mayor dignidad, obviamente, requerirá un mayor nivel de responsabilidad. Bartolomé de Medina, por ejemplo, aborda los pecados específicos de obispos, clérigos y sacerdotes, jueces, abogados y procuradores, escribanos, tutores y curadores, ejecutores de testamentos, médicos y cirujanos, mercaderes y oficiales, doctores y maestros, estudiantes, niños, casados y religiosos, dejando de lado por completo el universo del trabajo manual (90), que es contemplado con profusión en la obra de Alcocer, que llega a distinguir entre los pecados de sastres, calceteros, jubeteros, labradores, costureras, tundidores, plateros, confiteros, mesoneros, curtidores, zapateros, cereros, candeleros, carpinteros, cantereros, albañiles, veedores, examinadores y tasadores. Machado de Chaves, por su parte, dedica casi seiscientas páginas a las obligaciones de los distintos estados, de las cuales unas 350 se refieren al clero, 14 a reyes y señores, 19 a los jueces, 15 a fiscales, abogados, secretarios y alguaciles, 10 acusadores, reos y testigos, 7 a soldados y marinos, 8 a maestros y estudiantes, 70 a esposos, padres, hijos, señores y siervos, 8 a los médicos, 20 
a los mercaderes, corredores y regatones, y solamente 6 a los distintos oficios artesanales (91). Idéntica desproporción observaremos en la obra de Busenbaum: 38 páginas dedicadas en exclusiva a los clérigos, y 23 donde se abordan los pecados específicos de jueces, abogados, relatores, secretarios, notarios, procuradores, acusadores, testigos, reos, médicos, boticarios, cirujanos, mercaderes, oficiales, y «demás seculares» (92). Por supuesto, la gran ausencia la constituyen las mujeres (93), que solamente aparecen como entes diferenciados en cuanto a la forma que adquiere su relación de dependencia frente al varón, en atención a los típicos estados de doncellas, casadas, viudas y monjas (94).

Cada uno de dichos estados se caracterizará por sus pecados específicos, aunque a grandes rasgos se pueden resumir en dos aspectos: los derivados del ejercicio del poder, y los innúmeros fraudes cometidos por todas las profesiones. $\mathrm{Y}$ el «potencial pecaminoso» de cualquiera de los estados analizados es, sencillamente, desolador. Los reyes, por ejemplo, intentan conseguir nuevos reinos contra todo derecho, hacen guerras injustas, tienen diferencias con otros príncipes cristianos (95), venden los oficios a quienes son incapaces de ejercerlos dignamente o por un precio tan alto «que cree o debe crer que no los ejercitarán sin de ello desollar a los súbditos» (96), imponen tributos contra derecho sin necesidad, promulgan leyes en provecho propio y no en beneficio del bien común (97)...

Bartolomé de Medina se ocupará de lo que considera «el primer estado», constituido por «grandes, duques, condes y otros señores». Están obligados a poseer sus mayorazgos con justo título, debiendo los confesores tener especial cuidado con quienes vienen de las Indias, ya que se les ha de preguntar «como adquirieron tantas riquezas porque si son conquistadores con título injusto hanlo de restituir todo pero si son virreyes o tiene otros oficios reales si en la ejecución de ellos guardan las leyes de Dios y del rey aunque sean muy ricos no peca ni tiene obligación a restituir pero si lo han adquirido por contrataciones y mercaderías, lo mismo se ha de decir de ellos que de los mercaderes de España que si han hecho contratos ilícitos y otros engaños y fraudes son obligados a restituir y los que han sido conquistadores no sólo han de restituir la hacienda mal ganada sino que de su propio patrimonio si le tuvieren han de recompensar los daños hechos a los indios». Alude además a los numerosos abusos cometidos por los señores: imponer nuevos tributos, pechos y alcabalas a sus súbditos, obligarles a trabajar en sus heredades, apropiarse de los propios de los lugares bajo su dominio, vender los oficios públicos sin tener derecho para ello, ejercer la justicia de forma más rigurosa con los pobres, permitir pecados escandalosos en sus dominios tales usuras, hurtos y homicidios, no pagar a sus criados, prohibir que se cace en sus tierras, y excederse en su indumentaria «más de lo que conviene y es decente a la religión cristiana» (98).

Los soldados constituyen un grupo con el cual hay que tener un especial cuidado, por cuanto «muchas injusticias suelen hacer los soldados en las marchas o por los caminos y tierras por donde pasan en que pecan 
gravemente...gravísimos suelen ser los hurtos que los soldados cometen particularmente los bisoños que piensan que el entrar en la milicia es entrar a una vida licenciosa...las torpezas y sensualidades son vulgarísimas en ellos, y es horror oir las blasfemias, juramentos y execraciones que exhalan sus perniciosas lenguas ultrajando sin respeto ni fe ni religión...los duelos son también en ellos muy frecuentes muchas veces dejan de oir misa...son descuidadísimos en la frecuencia de los sacramentos y aun algunos y muchos no confiesan ni comulgan por la pascua en el juego son viciosísimos día y noche suelen gastar en esto perdiendo el estipendio que se les paga y roban cuando no se les paga para jugar de que resultan en ellos mil impaciencias enfados riñas duelos blasfemias y maldiciones, la murmuración es en ellos muy ordinaria» (99).

De los jueces se insiste sobre todo en su capacitación profesional y en el respeto a la inmunidad eclesiástica (100), así como en que ejerzan su oficio con fidelidad, sin recibir dones ni presentes ni hacer que los pobres sean despachados con brevedad (101). Abogados y procuradores deben procurar ser capaces de ejercer su oficio (es pecado perder un pleito por negligencia o ignorancia), no llevar pleitos injustos, ni cobrar un salario excesivo ni ayudar a la parte adversa, aunque se condena igualmente hacer perder al adversario si la causa de éste es justa. Esta fidelidad a la verdad se extiende además a denunciadores, acusadores, reos, y testigos (102). Los escribanos han de hacer escrituras de cuanto vieren $u$ oyeren sin incurrir en falsedad alguna, no deben revelar los secretos, hacer contratos usurarios ni cualquier otro ilícito, llevar un registro de todos los documentos, y cumplir fielmente con su oficio sin hacer escritura falsa ni romper $u$ ocultar la verdadera (103). No se olvida tampoco el mundo de la enseñanza, tanto por lo que se refiere a los maestros (104) como a los estudiantes (105).

Numerosos problemas de conciencia presentan los comerciantes, por cuanto sus pecados «son casi infinitos», si bien «es de notar que ser mercader por ganar es oficio vil y vituperable pero ser mercader por bien de la república y de su casa no es infamia» (106). Entre sus numerosas faltas, se encuentran aplicar cambios ilícitos y usuras, vender al fiado, pagar por adelantado o comprar heredad con pacto de retrovendo, llevar a los infieles hierro o armas sin licencia del Papa o con ella cuando es en perjuicio de los cristianos, practicar monopolios, defraudar las alcabalas y tributos, pagar con falsas monedas, violar los días de fiesta vendiendo o haciendo cuentas, mediar en malos contratos, defraudar en los pesos y medidas, dar mercancía dañada, venderla a más de su precio o pagar menos de lo que vale, no pagar las deudas a su tiempo haciendo daño a los acreedores y negociantes, pagar a sus acreedores contra su voluntad en mercaderías y vender mercancías en la Iglesia (107). Muy relacionados con éstos, los ricos, no deben perder de vista que sus riquezas han de destinarse a que «con ellas sean socorridos los pobres que son sus hijos» (108), lo que resume de forma bastante elocuente la doctrina católica acerca de la justa utilización de la riqueza. 
Por lo que se refiere a los artesanos, Alcocer da una serie de normas generales para aplicarlas a cualquier profesión:

«Cualquiera que acepta y usa algún oficio y arte sin tener la suficiencia que se requiere peca mortalmente y todo el tiempo que continúa o tiene voluntad de continuar el tal oficio o arte está en pecado mortal y todo el daño que causa por faltarle la suficiencia necesaria es obligado a lo restituir...El que por malicia o descuidarse en su oficio o arte hace algún daño peca mortalmente y es obligado a restituirlo...Aquel que por lo que toca a su oficio o arte lleva demasiado por llevar más de la tasa o del precio común más subido o por dar mala medida o peso o defraudar algo de lo que se le confió y entregó peca mortalmente y es obligado a lo restituir. Aquel peca mortalmente quien se mueve a hacer alguna cosa en su oficio por envidia o venganza o odio mortal o por otro fin de pecado mortal aunque la obra sea justa y la pueda hacer como el juez que se mueve a castigar al delincuente que lo merece por algunos destos respectos. Aquel peca mortalmente que se huelga deliberadamente del daño notable de algún oficial o le pesa de su bien notable o se lo estorba o procura estorbar...Todo aquel que con su oficio o arte puede socorrer al prójimo que padece extrema o grande necesidad peca mortalmente. Y si por razón de su oficio era obligado a ello es obligado al daño que le sucedió por no le socorrer. Pero sino le obligaba su oficio a ello sino sóla la caridad auque pecó mortalmente por no le remediar no es obligado a le restituir el daño. De aquí es que los abogados procuradores médicos cirujanos boticarios y los semejantes que conocen tener algún pobre necesidad grande de su oficio y no haber quien los socorra en ella pecan mortalmente en no los ayudar...No solamente los que hacen algunos de los pecados que se coligen de estas doctrinas y de los que ponen en los oficios y artes particulares pecan mortalmente mas también los que les ayudan y son partícipes de sus culpas».

Los pecados concretos de los distintos oficios se resumen en los diferentes fraudes profesionales cometidos por cada uno de ellos, y estos desafueros no tienen nada que envidiar a los descritos en nuestra novela picaresca (109). Los sastres, calceteros y jubeteros, por ejemplo, pecan por «hurtar alguna seda $o$ daño o otra cualquiera cosa de que hacen las ropas. Echar a perderlas por tomar algo de ellas o por descuido o por no saber más». Los tundidores, «en echar a perder el paño que tunden y en hacer vender el paño por más de lo que vale y en decir que es bueno y de talle y siendo falso». Los plateros, en «labrar oro de menos de veinte quilates y plata de menos once dineros y cuatro granos. Echar cera en las sortijas si la dan a peso de oro y plata. Quitar algo del oro y esmalte por la disminución del esmalte sin saberlo su dueño. Trocar el oro y plata y dar otro no tan bueno. Gastar otro oro o plata no tan bueno como el que mostró. Decir que pesa menos el oro y plata que compran o que pesa más de lo que venden. Dar por el oro y plata menos de lo que vale sin entenderlo sus dueños o llevar más de lo que vale».

Los mesoneros, a su vez, suelen «llevar más de lo que tasa el arancel por la posada cama cebada y paja salvo cuando se lo dan de su voluntad sin lo pedir. 
LLevar demasiado por la comida...descuidarse de la guarda de lo que traen los huéspedes...tener en su casa o traer alguna poersona de que usen mal los huéspedes o consentirlo a ellos o a otros». Los curtidores tienen la nefasta costumbre de «echar mucha casca a los cueros porque sequen más y son falsos. Echar el cuero de vaca en agua caliente en la casca para que venga más presto porque se quema y es falso. Dar cuero de yegua o camello curtido por de vaca. Trocar el cuero que le dan a curtir por otro no tan bueno o dar otro no tan bueno como el que prime lo mostró». Los cereros, por su parte, tienen a gala «echar termentina o resina a las achas o cirios...echar la cera por colar porque lleva tierra y suciedad. Dar la cera blanca mezclada con amarilla o sebo. Dar las tortas de cera mezcladas con sebo o otra cosa...Trocar la cera o pavilo por otro no tan bueno o gastar pabilo o cera no tan buena como mostraron. Finalmente, los carpinteros, cantereros, albañiles, tapiadores y otros trabajadores tienden a «hacer mal la obra y en llevar por ella excesivo jornal y en trabajar perezosamente cuando andan a jornal y darse tanta prisa cuando toman la obra a destajo que vaya mal hecha o falsa» (110).

Al estamento eclesiástico se le dedica una particular atención, respondiendo nuevamente a la idea de que mayor dignidad requiere un mayor grado de responsabilidad. Los obispos están obligados a guardar mayor grado de perfección «que el estado de cualquier religioso aunque sea de la Cartuja porque está obligado a ser forma y dechado de toda perfección y virtud de abnegación del mundo y su pompa de la mortificación en todos los afectos humanos en la pobreza de espíritu castidad y honestidad y sobre todo en la caridad y en la liberalidad con los pobres» (111). De este modo los prelados han de ser caritativos, con sobrada doctrina, irreprensibles en sus costumbres, prudentes y discretos, hospitalarios no sólo con sus familiares sino también con los pobres y peregrinos. Deben además predicar el evangelio a los fieles, residir en sus iglesias (sin causa inexcusable a no ser que fuese llamado como presidente del consejo de Inquisición), visitar a sus ovejas, aunque no «con tanto fausto y pompa que escandalice a los pobres súbditos en lugar de consolarlos», proveer los beneficios a personas dignas y virtuosas, y velar por las viudas y huérfanos. A su vez, no han de desear obispado ni procurarlo por medios humanos ni favores, molestar a sus feligreses con nuevas cargas, ordenar a indignos o concederles beneficios evitando especialmente el caer en el nepotismo, ni dejar de socorrer a los pobres construyendo «hospitales para los por venir el cual es gravísimo pecado contra caridad y aun según muchos contra justicia porque la hacienda del obispo es para sustentación de pobres», aprovechar las rentas de su obispado para hacer mayorazgos o casas suntuosas que recuerden su memoria, a la vez que se les recuerda el deber de procurar que en sus tribunales se despachen las causas de los pobres (112).

Los curas, por su parte, deben administrar los sacramentos a sus feligreses, cuidar su ministerio con diligencia cumpliendo todas sus obligaciones, visitar a los pobres de la parroquia y procurarles limosnas especialmente a los vergonzantes y a los niños, cuidar de los enfermos y procurar que mueran sacramentados y haciendo testamento (113). Los religiosos, aunque 
traen grandes beneficios espirituales para la población (114), no están exentos de peligros: han de velar sobre las circunstancias por las que entraron en religión, no pasarse sin dispensa a otra orden menos rigurosa, no mentir sobre la aspereza de su congregación, guardar los tres votos y las constituciones de su religión, cumplir con sus oficios, cuidar por la elección de prelado, gastar su tiempo convenientemente y no ociosamente o en obras inútiles, evitar ser disoluto, murmurador, impaciente o negligente en la oración, y no practicar un amor desordenado a sus parientes y a las cosas terrenales (115). Se les previene asimismo para que no frecuenten los locutorios de monjas, por cuanto «rarísimas veces se excusa de pecado mortal por razón del escándalo y peligro porque semejantes devociones suelen ser ocasión próxima de que el amor sencillo y urbano se convierta en carnal y lascivo» (116).

También los predicadores tienen sus obligaciones específicas. Deben predicar con la pertinente licencia, no hacerlo estando en pecado mortal, no mentir en el sermón sobre verdades de la fe, buenas costumbres, historia de los santos, milagros, profecías o cualquier otra cosa, no predicar «cosas inútiles cuales son muchas cuestiones especulativas de teología y aun de derecho canónico y civil de poesía y filosofía o de hechos de romanos y cosas semejantes», ni hacerlo por vanidad ni por dinero, evitando mezclar «fábulas gracias jocosas que provocan a reir por deleitar a los oyentes». Tampoco deben criticar a los eclesiásticos por agradar a los legos «que comúnmente les son contrarios», lo cual es pecado mortal «porque no aprovecha a ellos y daña y escandaliza a los eclesiásticos y disminuye la reverencia y devoción a los legos acerca de los sacramentos que los clérigos dan consagran y administran", aunque «en general no les es vedado tocar los vicios de los prelados con tanto que lo hagan con tiento y con palabras y razones que no escandalicen» (117). En opinión de Rodríguez.Lusitano, «pecan gravísimamente los predicadores que se precian de hablar en el púlpito romance muy afectado trayendo muchas autoridades de poetas y gentiles para mostrar erudición y hacer cosquillas a las orejas corporales principalmente de los que no quieren ser reprendidos los cuales de ordinario no solamente no aprovechan con sus sermones mas aun dañan apartando los oyentes de oir los sermones de predicadores espirituales que predican la verdad y los hacen andar embaucados tras la mentira y vanidad de la gentilicia curiosidad y retórica mas humana que divina» (118).

No podían faltar los confesores, que pueden tener sus tentaciones particulares: ejercer dicho ministerio sin jurisdicción o estando en pecado mortal, carecer de compasión con los penitentes, solicitar en el sacramento de la confesión, no guardar el sigilo del mismo, preguntar al penitente por mera curiosidad más circunstancias de las necesarias, principalmente en cosas deshonestas, negarse a confesar a pobres y mendigos, absolver a quien no lo merecía o negarle la absolución a quien era digno de ella (119).

Las monjas, finalmente, no deben poseer celda propia ni recibir sin licencia del convento algo de valor. Han de evitar tener «devoto con escándalo» (120), así como obedecer a la abadesa en todo lo tocante al bien de la comunidad, 
sin ocultarle falta alguna, rezar el oficio divino, y no tener bandos en el votar o enemistades con otras monjas, debiendo, por supuesto, cumplir estrictamente con la clausura. En el hábito, no deben tener cosas que escandalicen ni introducir galas indecentes a la religión (121). Sobre el adomo y compostura de las monjas, Machado indicará cómo «el adornarse las monjas con demasiado cuidado es absolutamente pecado mortal contra la virtud que profesan. Con todo afirman graves autores que como se haga por sola liviandad de ostentar la hermosura del rostro o del cuerpo sin mala intención no excede de pecado venial porque todo ello no viene a ser contra la caridad de Dios ni del prójimo. Mas si la religiosa compuesta con este cuidado se mostrase a los seglares y ellos por esta ocasión se incitasen gravemente los mismos doctores consienten en que pecaría mortalmente» (122).

No se agota aquí el contenido de los manuales de confesores. Hay bastante información, por ejemplo, sobre todo lo relativo al matrimonio y las relaciones familiares (123), defendiéndose claramente un modelo patriarcal de célula familiar (como botón de muestra, en casi todos los Manuales se defiende el derecho de corrección) (124), y reflejándose una gran preocupación por los distintos deberes de cada uno de los componentes de la familia, antes que por la necesidad de que exista afecto y amor entre sus componentes (125). Pero también se abordan un sinfín de cuestiones, tales el juego (126), el aborto (127), la hechicería (128), la guerra (129), la impotencia (130), los bailes (131), las corridas de toros (132), la prostitución (133), los desposorios (134), el divorcio (135), el consumo de tabaco (136), las actitudes ante la usura y el préstamo a interés (137)...e incluso algunas cuestiones teológicas que nos pueden resultar chocantes (que habrá que relacionar, nuevamente, con el amor a la casuística tan caro al probabilismo), como si es lícito bautizar con un líquido que no sea agua (138), o si se ha de administrar dicho sacramento a los individuos que han nacido con alguna deformidad (139).

En conclusión: los Manuales de confesores no constituyen el reflejo angélico de una Teología inmutable, antes al contrario, son claros hijos de su tiempo. Lo son por su notable flexibilidad doctrinal, al menos hasta el siglo XVIII, fruto del fuerte impacto que en España tuvieron hasta entonces las doctrinas probabilistas. Lo son por su concepción organicista y estamental de la sociedad, donde a cada status corresponde una serie de obligaciones específicas. Lo son por sus frecuentes concesiones a lo mágico-sobrenatural, dignas de ser abordadas en un trabajo específico. Y lo son, finalmente, por su marcada concepción patriarcal del universo familiar y la manifiesta posición subordinada de la mujer y los hijos. Serán el reflejo evidente, como no podía ser menos, de una doctrina católica fuertemente imbricada con el orden establecido, mostrando siempre una formidable capacidad de adaptación ante (un término muy caro a nuestros confesores) «las circunstancias». 


\section{NOTAS.}

(1) Cayetano Huarte, «El familiar del obispo», en MORGADO GARCIA, A., Iglesia e Ilustración en el Cádiz del siglo XVIII. Cayetano Huarte (1741-1806), Cádiz, 1993, p. 210.

(2) Cfr. ALEJANDRE, J.A., El veneno de Dios. La Inquisición de Sevilla ante el delito de solicitación en confesión, Madrid, 1994; SARRION MORA, A., Sexualidad y confesión. La solicitación ante el Tribunal del Santo Oficio (siglos XVI-XIX), Madrid, 1994; DUFOUR, G., Clero y sexto mandamiento. La confesión en la España del siglo XVIII, Valladolid, 1996.

(3) DELUMEAU, J., La confesión y el perdón, Madrid, Alianza, 1992, p. 15.

(4) Cfr. DELUMEAU, J., El miedo en Occidente, Madrid, 1989.

(5) DUFOUR, G., op. cit., p. 20.

(6) MARTIN RIEGO, M., «Las conferencias morales y la formación permanente del clero hispalense en el siglo XVIII», Isidorianum, 7, 1995.

(7) CARO BAROJA, J., Las formas complejas de la vida religiosa. Religión, sociedad y carácter en la España de los siglos XVI y XVII, reed., Madrid, 1985, p. 294.

(8) VAZQUEZ, I., «Las controversias morales postridentinas», Historia de la Iglesia en España, vol. IV. La Iglesia en la España de los siglos XVII y XVIII, Madrid, BAC, 1979, pp. 461 y 464.

(9) Cfr. LARTIGUE, O., Les comportements religieux d'aprés l' etude du Manuel de confesseurs de doctor Martin de Azpilcueta Navarro de 1556, Memoire de Maitrise inédita, Universidades de Valladolid y Pau, 1993.

(10) Cfr. DAGUERRE, S., Comportements familiaux et morale sous l' Ancien Régime espagnol: la pratique de confession de Jaime de Corella, Memoria inédita de licenciatura, Universidades de Valladolid y Pau, 1991.

(11) Una visión de conjunto sobre el género en EGIDO LOPEZ, T., «Religión», en AGUILAR PIÑAL, F., Historia literaria de España en el siglo XVIII, Madrid, CSIC, 1996, pp. 750-760.

(12) PALAU Y DULCET, A., Manual del librero hispanoamericano. Indice, tomo 2 (pp. 145-150) y 7 (pp. 18-21), voces «Confesión» y «Teología moral», Ampurias-Oxford, 1982 y 1987. 
(13) NICOLAS ANTONIO, Bibliotheca Hispano Nova sive hispanorum Scriptorum qui ab anno MD ad MDCLXXIV floruere, Madrid, 1783, vol. 2, Apéndice, Sección VIII, «Moralia Theologica Philosophica Politico-Moralia».

(14) KAMEN, H., The Phoenix and the Flame. Catalonia and the Counter Reformation, New Haven, 1993.

(15) GOMEZ, Fray Anselmo, Tesoro de la sciencia moral, Valladolid, 1668.

(16) ALVAREZ SANTALO, L.C., «Librerías y bibliotecas en la Sevilla del siglo XVIII», Actas del II Coloquio de Metodología Histórica Aplicada. La documentación notarial y la historia, vol. 2, Santiago de Compostela, 1984.

(17) ALVAREZ SANTALO, L.C., «Adoctrinamiento y devoción en las bibliotecas sevillanas del siglo XVIII», La religiosidad popular, vol. 2. Vida y muerte. La imaginación religiosa, Barcelona, 1989.

(18) ALVAREZ SANTALO, L.C., «Librerías».

(19) WERUAGA PRIETO, A., Libros y lectura en Salamanca. Del Barroco a la Ilustración 1650-1725, Salamanca, 1993

(20) LAMARCA LANGA, G., La cultura del libro en la época de la Ilustración. Valencia 1740-1808, Valencia, 1994.

(21) MORGADO GARCIA, A., «Bibliotecas clericales en el Cádiz del siglo XVIII», Hispania Sacra, 42, 1991, pp. 355-356.

(22) Las obras citadas en este trabajo (indicadas por orden cronológico de la edición consultada) son las siguientes: Martín Azpilcueta Navarro, Manual de confesores y penitentes, Salamanca, Andrea de Portionariis, 1557; Fray Juan de Pedraza, Summa de casos de conciencia, Toledo, Francisco de Guzmán, 1567; Bartolomé de Medina, Breve instrucción de cómo se ha de administrar el sacramento de la penitencia, Salamanca, Herederos de Matías Gaft, 1579; Manuel Rodríguez «Lusitano», Summa de casos de conciencia con advertencias muy provechosas para confesores, Salamanca, Juan fernández, 1597; Francisco Ortiz Lucio, Compendio de todas las summas que comunmente andan y recopilación de todos los casos de conciencia, Madrid, Lorenzo de Ayala, 1598; Francisco de Toledo, Instrucción de sacerdotes y suma de casos de conciencia, Valladolid, Francisco Fernández de Córdoba, 1613; Pedro Mártyr Coma, Directorium curatorum o Instrucción de curas útil y provechoso para los que tienen cargo de animas, Lérida, Luis Manescal, 1614; Fray Alonso Vega, Suma llamada nueva recopilación y práctica del fuero interior, utilísima para confesores y penitentes, Barcelona, Sebastián de Cormellas, 1617; Fray Pedro de Ledesma, Segunda parte de la summa en la cual se cifra todo lo moral y casos de conciencia, Lisboa, Pedro Crasbeeck, 1617; Fray Francisco de Alcozer, Confesionario breve y provechoso para los penitentes, Alcalá de Henares, Juan 
Gracián, 1619; Antonio Fernández de Córdoba, Instrucción de confesores, Granada, Martín Fernández Zambrano, 1622; Enrique de Villalobos, Manual de confesores, Salamanca, Cussio, 1625; Fray Juan Enríquez, Compendio de casos morales ordinarios, Sevilla, Francisco de Lyra, 1634; y Cuestiones prácticas de casos morales, Córdoba, Salvador de Cea Tesa, 1646; Juan Machado de Chaves, Perfecto confesor y cura de almas, Madrid, Viuda de Francisco Martínez, 1647; Antonio de Quintanadueñas, Instrucción de ordenantes, Madrid, Melchor Sánchez, 1661; Busenbaum, Médula de la Teología moral, Madrid, Bernardo de Villadiego, 1667; Ambrosio de Filguera, Summa de los casos de conciencia que se disputan en la Teología moral, Madrid, Melchor Sánchez, 1667; Fray Anselmo Gómez, Tesoro de la sciencia moral y suplemento de las sumas más selectas y modernas que hasta ahora han salido, Valladolid, María de Pereda, 1668; Benito Noyden, Promptuario moral de cuestiones prácticas y casos repentinos en la teología moral para examen de curas y confesores, Madrid, Julián de Paredes, 1672; Raimundo Lumbier, Fragmentos varios morales en prosecución de los que están en la Suma de Arana, Zaragoza, Domingo Gascón, 1683; Jaime de Corella, Práctica de el confesionario y explicación de las 65 proposiciones condenadas por la Santidad de N.SS.P. Inocencio XI, $9^{a}$ impresión, Barcelona, Rafael Filgueró, 1690; Domingo Manero, Difiniciones morales muy útiles y provechosas para curas, confesores y penitentes, Pamplona, Juan Micón, 1690; Valentín de la Madre de Dios, Fuero de la conciencia obra utilissima para los ministros y ministerio de el Santo sacramento de la Penitencia, Madrid, Francisco Lasso, 1704; Francisco Lárraga, Promptuario de la Theologia moral muy util para todos los que se han de exponer de confesores, Madrid, Herederos de Antonio Román, 1709; Miguel García, Prontuario de la Teología moral muy util y necesario para los ministros de el Sacramento de la Penitencia, Madrid, Tomás Rodríguez Frías, 1726; Francisco Echarri, Directorio moral que comprehende en breve y claro estilo todas las materias de la Theologia moral, Barcelona, Joseph Altés, 1749; José Faustino Cliquet, Epítome florido o compendio de la flor de la Theología moral, Madrid, Joseph García Lanza, 1759; Bernardo Pacheco, Suma moral escrita en breve compendio, Madrid, Imprenta de los Herederos de la Viuda de Juan García Infanzón, 1760; Fray Juan Ascargorta, Manual de confessores ad mentem Scoti, Madrid, Imprenta de la Causa de la V.M., María de Jesús de Agreda, 1762; Vicente Ferrer, Suma moral para examen de curas y confesores, Murcia, Felipe Teruel, 1771; Manuel de Arceniega, Método práctico de hacer fructuosamente una confesión general de muchos años, Madrid, Pedro Marín, 1783.

(23) Parte de esta obra ha sido publicada por DUFOUR, G., Diálogo entre un Confesor y un penitente a propósito del sexto mandamiento, Alicante, 1994.

(24) Vid. los distintos pecados contra el sexto mandamiento en TOMAS Y VALIENTE, F., «El crimen y pecado contra natura», Sexo barroco y otras transgresiones premodernas, Madrid, 1990. Reflexiones sobre la sexualidad a través de los Manuales de confesores, en BERNOS, M., «La sexualité et les confesseurs a l' epoque moderne», Revue de l' Histoire des Religions, 4, 1992; 
HURTEAU, P., «Catholic moral discourse on male sodomy and masturbation in the Seventeenth and Eighteenth Centuries», Journal of the History of Sexuality, 1, 1993; y, para el caso español, la obra fundamental de VAZQUEZ GARCIA, F., y MORENO MENGIBAR, A., Sexo y razón. Una historia de la moral sexual en España (siglos XVI a XX), Madrid, Akal, 1997.

(25) Cfr. DELUMEAU, J., La confesión, pp. 51-69.

(26) Ya señalado por VAZQUEZ, I., op. cit., p. 471.

(27) MEDINA, B. de, op. cit., pp. 291v-293.

(28) TOLEDO, F. de, op. cit., pp. 154v-155v.

(29) VILLALOBOS, E. de, op. cit., p. 47v.

(30) CORELLA, J. de, op. cit., vol. 1, p. 280.

(31) VAZQUEZ, I., op. cit., p. 467.

(32) RODRIGUEZ LUSITANO, M., op. cit., vol. 1, p. 160.

(33) VILLALOBOS, E. de, op. cit., lib. 6, pp. 74-75.

(34) FILGUERA, A. de, op. cit., p. 331.

(35) ENRIQUEZ, J., op. cit., pp. 1-4.

(36) Asî́ sucede en manuales dieciochescos, como el de Fray Valentín de la Madre de Dios. Vid. DUFOUR, F., Clero y sexto mandamiento.

(37) AZPILCUETA, M. de, op. cit., p. 23.

(38) CORELLA, J. de, op. cit., vol. 1, p. 297.

(39) ENRIQUEZ, J., op. cit., p. 193.

(40) Ibidem, p. 194v.

(41) MADRE DE DIOS, V. de la, op. cit., p. 253.

(42) AZPILCUETA, M. de, op. cit., pp. 598ss.

(43) TOLEDO, F. de, op. cit., pp. 162-v.

(44) ARCENIEGA, M.. de, op. cit., pp. 137-140. 
(45) FERRER, V., op. cit., p. 175.

(46) VAZQUEZ, I., op. cit., pp. 472-473.

(47) FILGUERA, A. de, op. cit., p. 101.

(48) MEDINA, B. de, op. cit., pp. 209v-210.

(49) TOLEDO, F. de, op. cit., p. 106v.

(50) VILLALOBOS; E. de, op. cit., p. 35.

(51) Evidentemente, no se entiende aquí por jansenismo las proposiciones formuladas por Jansenio de Yprés acerca de la gracia, sino las posturas rigoristas desde el punto de vista moral y sacramental. Cfr. al respecto APPOLIS, E., Les jansenistes espagnols, Burdeos, 1966; y CEYSSENS, L., «Le jansénisme. Considerations historiques preliminaires á sá notion», Nuove Ricerche Storiche sul Giansenismo, Roma, 1954, cuya distinción entre jansenismo histórico y teológico asumimos por completo.

(52) MADRE DE DIOS, V. de la, op. cit., p. 248.

(53) ARCENIEGA, M. de, op. cit., p. 149. Esta dureza también la encontramos en algunas visitas pastorales: en la realizada en 1801 el canónigo penitenciario gaditano Cayetano Huarte será partidario de que «se use con los pecadores reincidentes de todo el rigor que se le niegue o difiera la absolución». En su sátira tercera, «Contra los errores en las doctrinas morales», dirá muy claramente cómo "ése no dar la absolución a todos/ me huele al execrable jansenismo» (MORGADO GARCIA, A., Iglesia e Ilustración, pp. 103 y 221).

(54) LUMBIER, R., op. cit., pp. 583-587.

(55) MANERO, D., op. cit., pp. 256-258.

(56) ECHARRI, F., op. cit., pp. 21-22.

(57) CLIQUET, J.F., op. cit., p. 258.

(58) FERRER, V., op. cit., p. 22.

(59) CORELLA, J. de, vol. 1, «Preámbulo para la inteligencia y modo de practicar este diálogo».

(60) AZPILCUETA, M. de, op. cit., pp. 25-29.

(61) QUINTANADUEÑAS, A. de, op. cit., p. 379. 
(62) AZPILCUETA, M. de, op. cit., pp. 25-29.

(63) CORELLA, J. de, op. cit., vol. 1, «Preámbulo para la inteligencia y modo de practicar este diálogo».

(64) Ibidem, «Lamentación contra la omisión y poco celo de algunos confesores».

(65) ORTIZ LUCIO, F., op. cit., pp. 259-260.

(66) GOMEZ, A., op. cit., p. 8.

(67) LARRAGA, F., op. cit., p. 87.

(68) ASCARGORTA, J., op. cit., pp. 62-63.

(69) DELUMEAU, J., op. cit., pp. 25ss.

(70) LARRAGA, F., op. cit., p. 60.

(71) ECHARRI, F., op. cit., p. 154.

(72) CORELLA, J. de, op. cit., vol. 1, p. 286.

(73) lbidem, «Preámbulo para la inteligencia y modo de practicar este diálogo», pp. 4 y 9 .

(74) RODRIGUEZ LUSITANO, M., op. cit., vol. 1, p. 233. Este rigor se encuentra muy en consonancia con las campañas de recristianización del siglo XVI: desde 1566 era necesario en el arzobispado de Toledo para recibir el sacramento de la comunión, conocer las cuatro oraciones básicas de la doctrina católica. Cfr. DEDIEU, J.P., L' administration de la foi. L'Inquisition de Toléde (XVIe-XVIIle siécles), Madrid, 1989.

(75) Vid. un ejemplo en SAAVEDRA, P., La vida cotidiana en la Galicia del Antiguo Régimen, Barcelona, Crítica, 1994. Todavía a finales del siglo XVI la Inquisición toledana debía enfrentarse al hecho de que el $30 \%$ de los procesados eran incapaces de recitar correctamente los Diez Mandamientos (DEDIEV, J.P., «Christianisation en Nouvelle Castille. Catechisme, communion et confirmation dans 1' archeveche de Toledo 1540-1650", Melanges de la Casa de Velázquez, XV, 1979.

(76) ORTIZ LUCIO, F., op. cit., p. 257.

(77) ENRIQUEZ, J., op. cit., p. 11. 
(78) NOYDEN, B.R., op. cit., p. 49.

(79) Entendiendo por tales aquellas zonas en las que predominaba una situación de ignorancia religiosa bastante generalizada. Cfr. KAMEN, H., op. cit.

(80) AZPILCUETA; M. de, op. cit., cap. V.

(81) MEDINA, B. de, op. cit., p. 236.

(82) CARO BAROJA, J., op. cit., p. 322. Los capítulos XIII, XV, XVI y XVII de esta obra fundamental utilizan en más de una ocasión como fuente los Manuales de confesores.

(83) No perdamos de vista la persistencia de la imagen estamental de la sociedad en el siglo XVII. Vid. MARAVALL, J.A., Poder, honor yélites en el siglo XVII, $2^{\text {a }}$ edición, Madrid, 1984.

(84) GARCIA, M., op. cit.

(85) A fines del siglo XVII Barcia y Zambrana en su «Despertador cristiano» llega a señalar que el religioso sigue el camino más seguro para la salvación del alma (MORGADO GARCIA, A., El estamento eclesiástico y la vida espiritual en la diócesis de Cádiz en el siglo XVII, Cádiz, 1996, p. 137).

(86) ALCOCER, F. de, op. cit., pp. 1v-6.

(87) MEDINA, B. de, op. cit., p. 218v.

(88) MACHADO DE CHAVES, J., op. cit., «Prolocución a los prelados».

(89) Sobre el peso de los distintos grupos sociales en la literatura devocional, cfr. ALVAREZ SANTALO, L.C., «El libro de devoción como modelado y modelador de la conducta social: el «Luz a los vivos» de Palafox (1668)», Trocadero, 1, 1989.

(90) MEDINA, B., op. cit., cap. 16.

(91) MACHADO DE CHAVES, J., op. cit., vol. 2.

(92) BUSENBAUM, op. cit., pp. 229-290.

(93) En la obra de Vega, por ejemplo, se abordan de forma genérica las «mujeres», sin entrar en particularidades, recomendándoles que «su aderezo y atavío es el silencio, la guarda de casa, el cuidado de la hacienda y la limpieza en todo y sobre todo la honestidad que es la principal virtud de las mujeres» (VEGA, A. de, op. cit., p. 780). 
(94) Cfr. VIGIL, M.L., La vida de las mujeres en los siglos XVI y XVII, Madrid, 1986.

(95) AZPILCUETA, M. de, op. cit., c. 25, p. 4.

(96) FERNANDEZ DE CORDOBA, A., op. cit., pp. 42-v.

(97) AZPILCUETA, M. de, op. cit., c. 25, p. 9.

(98) MEDINA, B. de, op. cit., pp. 218-219v.

(99) CORELLA, J. de, op. cit., vol. 2, p. 162.

(100) AZPILCUETA, M. de, op. cit., c. 25, pp. 12-20.

(101) MEDINA, B. de, op. cit., pp. 225v-226.

(102) AZPILCUETA, M. de, op. cit., pp. 28-45.

(103) Ibidem, c. 25, pp. 52-54.

(104) Ibidem, c. 25, pp. 55-58, MEDINA, B. de, op. cit., pp. 229v-230.

(105) AZPILCUETA, M. de, op. cit., c. 25, p. 59, y MEDINA, B. de, op. cit., p. 230-v.

(106) MEDINA, B. de, op. cit., p. $228 \mathrm{v}$.

(107) MEDINA, B. de, op. cit., p. 219-v; ALCOCER, F. de, op. cit., p. 31; FERNANDEZ DE CORDOBA, A., op. cit., pp. 39v-40.

(108) ORTIZ LUCIO, F., op. cit., p. 60.

(109) Se nos vienen a la memoria las antológicas páginas dedicadas en el Guzmán de Alfarache a los posaderos.

(110) ALCOCER, F. de, op. cit., pp. 108v-110.

(111) MEDINA, B. de, op. cit., pp. 220-223.

(112) Ibidem. Se limita a reflejar el modelo de obispo ideal puesto de relieve por TELLECHEA IDIGORAS, J.I., El obispo ideal en el siglo de la Reforma, Roma, 1963.

(113) FERNANDEZ DE CORDOBA, A., op. cit., pp. 58v-59. 
(114) Son muy interesantes al respecto las opiniones formuladas por Lumbier, para el cual «la gente rústica y en especial mujeres reparan mucho en el empacho de confesar su delito a persona que mucho las conoce» (en clara referencia a los curas), cosa que no sucede con los religiosos, «porque todos o algunos de ellos si hoy están en este convento ya mañana no están». Añade otras ventajas espirituales, como su actividad predicatoria o la enseñanza de la doctrina cristiana (LUMBIER, R., op. cit., pp. 613-615).

(115) MEDINA, B. de, op. cit., pp. 233-v.

(116) NOYDEN, B.R., op. cit., p. 161.

(117) AZPILCUETA, M. de, op. cit., c. 25, p. 141-143.

(118) RODRIGUEZ LUSITANO, M., op. cit., vol. 2, p. 97. Todas estas advertencias formuladas en los Manuales de confesores están muy en sintonía con la hilarante sátira que realiza el Padre Isla en su Fray Gerundio de Campazas contra aquellos predicadores que buscan agradar al público y no convertirlo.

(119) FILGUERA, A. de, op. cit., pp. 156-157. En su sátira tercera Cayetano Huarte advierte contra aquellos confesores que tienen una especial tendencia a absolver a los ricos y a los grandes señores (MORGADO GARCIA, A., Iglesia e Ilustración, p. 219).

(120) Las «devociones de monjas» fueron continuamente perseguidas por la jerarquía durante este período, y en el siglo XVIII prácticamente han desaparecido. Cfr. CANDAU CHACON, M.L., «Devociones y galanteos de monjas en la Sevilla de fines del Antiguo Régimen», I Congreso Internacional del Monacato Femenino en España, Portugal y América, tomo 2, León, 1993.

(121) FERNANDEZ DE CORDOBA, A., op. cit., pp. 55-56.

(122) MACHADO DE CHAVES, J., op. cit., vol. 2, p. 343.

(123) RODRIGUEZ LUSITANO, M., op. cit., vol. 1, pp. 23-32, TOLEDO, F. de, op. cit., pp. 1-39. La visión de la mujer a través de la literatura moral y religiosa ha sido profusamente estudiada: cfr. BARBAZZA, M.C., «L' épouse chretienne et les moralistes espagnols du XVIIe et XVIIIe siécles», Melanges de la Casa de Velázquez, XXIV, 1988; HERNANDEZ BERMEJO, M.A., «La imagen de la mujer en la literatura moral y religiosa de los siglos XVI y XVII», Norba, 8-9, 1987-1988; CORREIA FERNANDES, M.L., Espelhos, cartas e guias casamento e spiritualidade na Peninsula Iberica 1450-1700, Oporto, 1995. Una síntesis en las páginas escritas por M. Ortega López relativas a los siglos XVI-XVIII en la obra colectiva Historia de las mujeres en España, Madrid, Síntesis, 1997. 
(124) Una de estas excepciones viene dada por Cliquet, que señala que «aunque algunos dicen que puede el marido castigar moderadamente a su mujer habiendo causa yo más me inclino a que aunque haya causa no es lícito al marido poner manos en su mujer y que basta reprenderla y amonestarla» (CLIQUET, J.F., op. cit., p. 408).

(125) Ello ya ha sido señalado en los Manuales de confesores franceses por FLANDRIN, J.L., Orígenes de la familia moderna, Barcelona, 1979.

(126) VILLALOBOS, E. de, op. cit., p. 181v.

(127) ORTIZ LUCIO, F., op. cit., pp. 139-140; RODRIGUEZLUSITANO, M., op. cit., vol. 1, p. 7 .

(128) ORTIZ LUCIO, F., op. cit., pp. 96-99, RODRIGUEZ LUSITANO, M., op. cit., vol. 1, pp. 10-12, TOLEDO, F. de, op. cit., pp. 184v-189.

(129) BUSENBAUM, op. cit., pp. 133-135; ORTIZ LUCIO, F., op. cit., pp. 131-132.

(130) TOLEDO, F. de, op. cit., p. 123v.

(131) VEGA, A., op. cit., pp. 168-169.

(132) VILLALOBOS, E. de, op. cit., pp. 244v-245.

(133) FERNANDEZ DE CORDOBA, A., op. cit., pp. 30-31, LEDESMA, P., op. cit., p. 665 .

(134) VILLALOBOS, E. de, op. cit., pp. 63v-68.

(135) Ibidem, p. 83.

(136) Según Fray Anselmo Gómez, «hay cinco modos de tomar tabaco tres que se usan en nuestra España que son mascar la hoja beber el humo y sorber el polvo...ninguno quebranta el ayuno eclesiástico» (GOMEZ, A., op. cit., p. 26).

(137) Ya abordado por SANCHEZ LORA, J.L., «Beneficio comercial y justo precio en la Teología moral del siglo XVIII», La burguesía de negocios en la Andalucía de la Ilustración, tomo 2, Cádiz, 1991.

(138) «Tratemos primero de la materia remota y digo que ésta ha de ser agua elemental y así no es lícito bautizar con otro licor...y así con vino cerveza o leche no se puede bautizar ni con otros licores de yerbas flores o de árboles ni otras aguas destiladas por alambiques que no son elementales ni con sudor saliva ordina que son excrementos y no agua» (TOLEDO, F. de, op. cit., p. 139).

(139) BUSENBAUM, op. cit., p. 333. 